\title{
Protective effect of tomato against adrenaline-induced myocardial infarction in rats
}

\author{
Roksana Parvin and Nargis Akhter \\ Department of Pharmacology, Bangabandhu Sheikh Mujib Medical University, \\ Shahbag, Dhaka, Bangladesh.
}

\begin{abstract}
Lycopene, a carotenoid rich in tomato fruit (ripe), is an effective antioxidant and free radical scavenger. In this study n-hexane extract of tomato was evaluated for its protective action against oxidative stress in experimental myocardial infarction induced by administration of adrenaline in rats. Adrenaline produced significant elevation of malondialdehyde content of heart, an indicator of lipid peroxidation, with a significant rise in serum aspartate aminotransferase (AST) level and different grades of necrotic changes in myocardium. Rats were treated with two doses of n-hexane extract of tomato, intragastrically daily for one month prior to administration of adrenaline on the $31^{\text {st }}$ and $32^{\text {nd }}$ day. Pretreatment of tomato extract $(1 \mathrm{mg} / \mathrm{kg}, 2 \mathrm{mg} / \mathrm{kg})$ and vitamin E $(50 \mathrm{mg} / \mathrm{kg})$ significantly reduced the malondialdehyde concentration in heart and significantly lowered the serum AST level in adrenaline treated rats. Myocardial necrosis was significantly prevented by pretreatment. These results suggest that $n$-hexane extract of tomato possesses antioxidative property that may protect heart against catecholamine induced myocardial infarction.
\end{abstract}

\section{Introduction}

Myocardial ischemia occurs in acute myocardial infarction and exceeds a critical threshold level for an extended time period resulting in irreversible myocardial cell damage and death ${ }^{1}$. In early phase of MI circulating catecholamine level is strikingly increased $^{2}$ and is released from ischemic myocardium $^{3}$. Oxygen derived free radicals are generated in heart during cardiac ischemia. Free radicals and lipid peroxides have been identified as metabolic intermediates during acute myocardial infarction ${ }^{4}$. A burst of reactive oxygen-centered free radical generation occurs within moments of post ischaemic reperfusion ${ }^{5}$. In addition, autooxidation of catecholamine results in generation of highly cytotoxic free radicals ${ }^{6}$. It has been reported that during myocardial infarction, the natural antioxidant defense mechanisms (i.e., superoxide dismutase, catalase, GSH) are depleted. Subsequently myocardial ischaemic tissue becomes vulnerable to any types of oxidative stress ${ }^{5}$. Oxygen radicals initiate injury propagation by lipid peroxidation in myocardial cell membrane. Lipid peroxidation, an established mechanism of cellular injury, is particularly active during reperfusion of ischaemic myocardium ${ }^{7}$. Thus, malondialdehyde, a lipid peroxidation product, is used as an indicator of oxidative stress in cells and tissues ${ }^{8}$. Antioxidant vitamins commonly chosen in the prevention of IHD not only because of their efficacy as antioxidant but also because of their clinical relevance and minimum toxicity. The alpha form of vitamin $\mathrm{E}$ is the most biologically active and prevents the formation free radicals. Vitamin $\mathrm{C}$ is another potent antioxidant located in extracellular fluid and traps peroxyl radicals in aqueous phase and inhibits lipid peroxidation 9 .

Diet rich in fruits and vegetables containing carotenoids have been of interest because of their potential health benefits against ischaemic heart disease. Although $\beta$-carotene has been investigated for many years, lycopene, a carotenoid and an acyclic isomer of $\beta$-carotene, has attracted substantial interest more recently ${ }^{10}$. Studies have indicated that lycopene is an effective antioxidant and free radical scavenger ${ }^{11}$. Because of its high number of conjugated double bonds, lycopene exhibits higher singlet oxygen quenching ability compared to $\alpha$ tocopherol or $\beta$-carotene ${ }^{12}$.

Tomato extract containing lycopene is a red color pigment and is widely distributed in a wide variety of fruits and vegetables. At least $85 \%$ of our dietary lycopene comes from tomato fruit (ripe), tomato based products, the remainder being obtained from papaya, water melon, pink grapefruit and guava ${ }^{10}$. 
At present, the role of lycopene in the prevention of ischaemic heart disease is strongly suggestive. Lycopene can be obtained by dietary consumption of tomato. As a food product it has no adverse effects and can be consumed throughout the year. With this view the present study has been designed to investigate the possible protective effect of nhexane extract of tomato in adrenaline induced myocardial infarction in rats.

\section{Materials and Methods}

Animals: The study was carried out on healthy adult rats (Norwegian strain) aged between 3-4 months of both sexes and weighing between 220260 g. They were kept in medium sized plastic cages. They were allowed to live at room temperature, fed on standard pellets of rat's food and allowed to drink water ad libitum.

Chemicals and reagents: Adrenaline was purchased from local market. Vitamin E was obtained from Square Pharmaceuticals. AST kits and protein estimation kits were purchased from RANDOX Laboratories, UK and Human Gmbh, Germany respectively. Thiobarbituric acid was bought from Sigma Chemical.

Preparation of n-hexane extract of tomato: The instrument used to prepare n-hexane extract of tomato is known as rotary vacuum evaporator. Ripe tomatoes were brought from local market and cleaned properly, cut into small pieces and soaked into n-hexane in clean amber colored glass containers for 24 hours. Two kilogram tomatoes were soaked in 2 liters of n-hexane at a time. After that, tomato was filtered properly and condensed by rotary vacuum evaporator at $40^{\circ} \mathrm{C} .40 \mathrm{ml}$ of tomato extract was obtained from $2 \mathrm{~kg}$ tomatoes. For this procedure a total $10 \mathrm{~kg}$ of tomato were soaked in 10 liters of n-hexane. In this way total $200 \mathrm{ml}$ of tomato extract was obtained. The extract was freeze dried and kept in amber colored bottle and preserved at $0^{\circ}$ to $4^{\circ} \mathrm{C}$ in deep freezer.

The active ingredient of vitamin $\mathrm{E}$ and freeze dried n-hexane extract of tomato were diluted in olive oil.

Experimental design: Rats were randomly divided into seven groups and were treated as follows:

Group I received distilled water $\left(\begin{array}{ll}1 & \mathrm{ml}\end{array}\right)$ subcutaneously (s.c.) once daily for two consecutive days (24 hours apart) and served as control. Group II was treated with n-hexane extract of tomato $1 \mathrm{mg} / \mathrm{kg}$ orally daily (through intragastric tube) for one month ${ }^{13}$. Group III received vitamin $\mathrm{E}$ $50 \mathrm{mg} / \mathrm{kg}$ intragastrically daily for one month ${ }^{14}$. Group IV received adrenaline $2 \mathrm{mg} / \mathrm{kg}^{14}$ subcutaneously once daily for 2 consecutive days (24 hours apart). Group V, VI and VII received nhexane extract of tomato $(1 \mathrm{mg} / \mathrm{kg}, 2 \mathrm{mg} / \mathrm{kg})$, and vitamin $\mathrm{E}$ respectively for one month followed by adrenaline on $31^{\text {st }}$ and $32^{\text {nd }}$ day (as Group IV). The rats were sacrificed $24 \mathrm{hrs}$ after the last dose under light anesthesia with chloroform. 3-4 $\mathrm{ml}$ of blood was collected from carotid artery in a clean test tube by cutting the neck of animal. The serum was separated by centrifugation $(1,725 \mathrm{x}$ g for $5 \mathrm{~min})$. The heart was isolated and some portion of atria and ventricle was preserved in formalin $(37 \%$ formaldehyde) for histopathology. The remaining portion of heart was homogenized on ice bath for biochemical estimation of malondialdehyde and protein.

Estimation of serum AST level: Serum AST level was estimated by using UV method ${ }^{15}$. The concentration of enzyme was measured in spectrophotometer (Micro Flow Cell Photometer AE-100F ERMA Inc) at $340 \mathrm{~nm}$ wavelength.

Estimation of protein: The protein content of heart tissue homogenate was estimated by Lowry's method $^{16}$ and the absorbance was measured by using spectrophotometer at $600 \mathrm{~nm}$ wave length. Bovine serum albumin was used as standard.

Estimation of malondialdehyde: The product of lipid peroxidation, thiobarbituric acid reactive substance (TBARS) was estimated ${ }^{17}$. The absorbance was measured by spectrophotometer at $532 \mathrm{~nm}$ wave length.

Histological procedure: Some portion of atria and ventricle of heart was fixed in formalin, dehydrated in graded alcohol and embedded in paraffin wax, sectioned at $5 \mu \mathrm{m}$ thickness and stained with hematoxylin and eosin (H\&E) for microscopic examination. The lesions of heart were graded according to Rona et $\mathrm{al}^{18}$.

Statistical analysis: All the results were appropriately recorded in a tabulated form in the computer. Values were expressed as mean \pm SEM, where SEM represent the standard error of mean. Students unpaired ' $t$ ' test and $\chi 2$ test was performed to evaluate the level of significance which was set at $p$ values of 0.05 to 0.001 .

\section{Results}

Results in Table I revealed that administration of nhexane extract of tomato and vitamin $\mathrm{E}$ did not produce any significant change in serum AST level and myocardial MDA content when compared with the control. 
Table I: The effect of pretreatment of n-hexane extract of tomato and vitamin E on serum AST level and myocardial malondialdehyde concentration in adrenaline treated rats

\begin{tabular}{|c|c|c|c|c|c|}
\hline Treatment & $\mathrm{n}$ & $\begin{array}{l}\text { Serum AST } \\
(\mathrm{U} / \mathrm{L})\end{array}$ & $\begin{array}{c}\text { Percentage of } \\
\text { prevention by } \\
\text { pretreatment }\end{array}$ & $\begin{array}{c}\text { Malondialdehyde } \\
\text { (MDA) nmol/mg } \\
\text { protein }\end{array}$ & $\begin{array}{r}\text { Percentage of } \\
\text { prevention by } \\
\text { pretreatment } \\
\end{array}$ \\
\hline n-Hexane extract of tomato & 6 & $207.3 \pm 3.4$ & & $1.54 \pm 0.016 \mathrm{NS}$ & \\
\hline Vitamin E & 6 & $205.3 \pm 3.4$ & & $1.64 \pm 0.019 \mathrm{NS}$ & \\
\hline $\begin{array}{l}\mathrm{n} \text {-Hexane extract of tomato }(1 \mathrm{mg} / \mathrm{kg})+ \\
\text { Adrenaline }\end{array}$ & 9 & $350.55 \pm 17.37$ & 35 & $2.12 \pm 0.007 * * *$ & 51 \\
\hline $\begin{array}{l}\mathrm{n} \text {-Hexane extract of tomato }(2 \mathrm{mg} / \mathrm{kg})+ \\
\text { Adrenaline }\end{array}$ & 9 & $316.82 \pm \underline{9} .61$ & 50 & $1.85 \pm 0.012 * * *$ & 75 \\
\hline
\end{tabular}

Data expressed as mean $\pm \mathrm{SE} ; * * *=\mathrm{p}<0.001 ; \mathrm{NS}=$ not significant; $\mathrm{n}=$ number of rats

Serum AST level (mean \pm SE) in the adrenaline treated $(2 \mathrm{mg} / \mathrm{kg}$, two successive inj.) and control (distilled water) groups were $476.12 \pm 5.69 \mathrm{U} / \mathrm{L}$ and $197.3 \pm 4.6 \mathrm{U} / \mathrm{L}$ respectively. The rise in serum AST level in adrenaline treated group was significant $(\mathrm{p}<0.001)$. Pretreatment with nhexane extract of tomato decreased the adrenaline induced rise in serum AST level. Administration of $\mathrm{n}$-hexane extract of tomato 1 $\mathrm{mg} / \mathrm{kg}$ for one month lowered the serum AST level to $350.55 \pm 17.37 \mathrm{U} / \mathrm{L}$ and the decrease was significant $(\mathrm{p}<0.001)$. Pretreatment with a higher dose $(2 \mathrm{mg} / \mathrm{kg})$ of extract of tomato reduced the AST level to $316.82 \pm 9.61 \mathrm{U} / \mathrm{L}$ and the reduction was significant $(\mathrm{p}<0.001)$. Vitamin E pretreatment $50 \mathrm{mg} / \mathrm{kg}$ for one month before adrenaline administration decreased the serum AST level to $292.6 \pm 7.41 \mathrm{U} / \mathrm{L}$ and the reduction was significant $(\mathrm{p}<0.001)$. $\mathrm{n}$-Hexane extract of tomato in a dose of $1 \mathrm{mg} / \mathrm{kg}$ and $2 \mathrm{mg} / \mathrm{kg}$ prevented the adrenaline induced rise of serum AST level by $35 \%$ and $50 \%$ respectively. Vitamin E pretreatment prevented the adrenaline induced rise in serum AST level by $57 \%$.

A significant increase in lipid peroxidation was induced in heart as indicated by rise in malondialdehyde level in myocardial tissue. The malondialdehyde levels in adrenaline treated and control group were $3.22 \pm 0.011 \mathrm{nmol} / \mathrm{mg}$ protein and $1.52 \pm 0.0085 \mathrm{nmol} / \mathrm{mg}$ protein respectively and the rise was significant $(<0.001)$. Pretreatment of $n$-hexane extract of tomato in a dose of $1 \mathrm{mg} / \mathrm{kg} \mathrm{\&} 2 \mathrm{mg} / \mathrm{kg}$ for one month before adrenaline administration reduced the malondialdehyde level to $2.12 \pm 0.0070$ $\mathrm{nmol} / \mathrm{mg}$ protein and $1.85 \pm 0.012 \mathrm{nmol} / \mathrm{mg}$ protein respectively. Both the decrease was significant $(\mathrm{p}<0.001)$. Administration of vitamin E $(50 \mathrm{mg} / \mathrm{kg})$ for one month reduced the malondialdehyde level to $1.92 \pm 0.0068 \mathrm{nmol} / \mathrm{mg}$ protein and the reduction was significant $(\mathrm{p}<0.001)$. $\mathrm{n}$-Hexane extract of tomato pretreatment with two different doses prevented the adrenaline induced rise in malondialdehyde level by $51 \%$ and $75 \%$ respectively. Treatment with vitamin $\mathrm{E}$ prevented the adrenaline induced rise of malondialdehyde level in heart by $67 \%$.

The rats that received two subsequent doses of adrenaline showed different grades of necrotic areas in the ventricles. Administration of n-hexane extract of tomato and vitamin $\mathrm{E}$ prevented the induction of grade III \& IV lesions in myocardium of adrenaline treated rats (Table II).

Table II: The percentage of lesion in myocardium following pretreatment of $\mathrm{n}$-hexane extract of tomato and vitamin $\mathrm{E}$ in adrenaline treated rats

\begin{tabular}{llllc}
\hline & \multicolumn{3}{c}{ Grade of lesion (G) } \\
\cline { 2 - 5 } & G-0 & G-I & G-II & G-III \& IV \\
\hline $\begin{array}{l}\text { Adrenaline }(\mathrm{n}=9) \\
\text { n-Hexane extract of } \\
\text { tomato 1 mg/kg }+\end{array}$ & & $10 \%$ & $30 \%$ & $60 \%$ \\
Adrenaline (n=9) & $50 \%$ & $30 \%$ & $20 \%$ & - \\
n-Hexane extract of & & & & \\
$\begin{array}{l}\text { tomato 2 mg/kg }+ \\
\text { Adrenaline (n=9) }\end{array}$ & $60 \%$ & $20 \%$ & $20 \%$ & - \\
$\begin{array}{l}\text { Vitamin E + } \\
\text { Adrenaline }(\mathrm{n}=6)\end{array}$ & $70 \%$ & $20 \%$ & $10 \%$ & - \\
\hline
\end{tabular}

$\mathrm{n}=$ number of rats; G-0: No lesion; G-I: Fibroblastic swelling, accumulation of histiocyte; G-II: Edema, mottled staining, fragmentation and segmentation of muscle fiber; G-III: Marked capillary dilatation, hemorrhage, extensive edema; G-IV: Similar to Grade-III but more extensive

\section{Discussion}

Antioxidants vitamins are believed to have potential health benefit against ischemic heart disease. Lycopene, a dietary antioxidant, is the most potent singlet oxygen quencher among the natural carotenoids $^{12}$. Lycopene, a red color pigment, is obtained from tomato and a variety of fruits and 
vegetables ${ }^{10}$. Lycopene may provide protection against free radical mediated oxidative myocardial damage.

The purpose of this investigation was to assess the potential protective role of $n$-hexane extract of tomato on adrenaline induced myocardial damage in rats and to reveal the possible mechanism of protection. The results of this study showed cardiac protection by prophylactic treatment of n-hexane extract of tomato in two different doses $(1 \mathrm{mg} / \mathrm{kg} \& 2 \mathrm{mg} / \mathrm{kg})$ for one month before administration of adrenaline ( 2 $\mathrm{mg} / \mathrm{kg}$ in two subsequent doses), as evidenced by biochemical and histopathological changes in the heart. The biochemical parameter, AST level had been greatly reduced. The histopathological changes such as mononuclear cellular infiltration, mottled staining, interstitial edema, fragmentation and segmentation of muscle fiber, vacuolar degeneration and capillary dilatation were greatly reduced and Grade III \& IV lesions were absent with both the doses of n-hexane extract of tomato. However, in a comparative study vitamin $\mathrm{E}$ was found to be more effective in reducing serum AST level and in improving histopathological changes.

In this study adrenaline caused significant increase in malondialdehyde concentration in heart, indicating increased lipid peroxidation.This is in agreement with several other reports. Free radicals and lipid peroxides as metabolic intermediates were identified during $\mathrm{AMI}^{4}$. Reactive oxygen centered free radicals are also been found to be generated in heart during ischaemia ${ }^{5}$.Oxygen radicals initiate injury propagation by lipid peroxidation in myocardial cell membrane and may result in loss of membrane integrity. Lipid peroxidation is particularly active during perfusion of ischemic myocardium ${ }^{7}$. It has been shown that myocardial malondialdehyde level is increased significantly after administration of isoproterenol ${ }^{19}$. Our result supports the hypothesis that adrenaline has got the ability to produce free radicals which enhance lipid peroxidation, a basic detoriative process in the cell which results in increase in serum AST, as well as contributing to the pathological change in the myocardial cells.

Pretreatment with two different doses of nhexane extract of tomato produced significant reduction in malondialdehyde concentration in heart after adrenaline treatment. It has been suggested that decreased oxidative modification of LDL may be one of the mechanisms by which lycopene may reduce the risk of $\mathrm{CHD}$ and atherosclerotic process ${ }^{7}$. It may be presumed that lycopene because of its singlet oxygen quenching ability $^{12}$ prevents oxidative stress of heart and inhibits lipid peroxidation and thus maintains the cellular integrity and decreases the release of cardiac enzymes into blood. All these factors contribute to the improvement of histopathology of heart.

It may be concluded that the generation of oxygen derived free radicals may be an important event in the development of adrenaline induced myocardial damage. n-Hexane extract of tomato because of its antioxidant property prevents this free radical mediated injury of heart and thus might exert a potential cardioprotective role in myocardial infarction.

\section{References}

1. Fox KAA. Acute coronary syndromes: Presentationclinical spectrum and management. Heart 2000; 84: 93100.

2. Gazes PC, Richardson JA, Woods EF. Plasma catecholamine concentration in myocardial infarction and angina pectoris. Circulation 1959; 19: 657-61.

3. Karlsberg RP, Cryer PE, Roberts R. Serial plasma catecholamine response early in the course of clinical acute myocardial infarction: Relationship to infarct extent and mortality. Am Heart J. 1981; 102: 24-29.

4. Rao PS, Cohen MV, Mueller HS. Production of free radicals and lipid peroxides in early experimental myocardial ischemia. J Mol Cell Cardiol. 1983; 15: 71316.

5. Zweier JL, Flaherty JT, Weisfeldt ML. Direct measurement of free radical generation following reperfusion of ischemic myocardium. Proc Natl Acad Sci. 1987; 84: 1404-07.

6. Singal PK, Kapur N, Dhillon KS, Beamish RE, Dhalla NS. Role of free radicals in catecholamine-induced cardiomyopathy. Can J Physiol Pharmacol. 1981; 60: 1390-97.

7. Rao AV. Lycopene, tomatoes, and the prevention of coronary heart disease. Exp Biol Med. 2002; 227: 908-13.

8. Janero DR. Malondealdehyde and thiobarbituric acidreactivity as diagnostic indices of lipid peroxidation and peroxidative tissue injury. Free Radic Biol Med. 1990; 9: $515-40$.

9. Shite J, Qin F, Mao W, Kawai H, Stevens SY, Liang C. Antioxidant vitamins attenuate oxidative stress and cardiac dysfunction in tachycardia-induced cardiomyopathy. J Am Coll Cardiol. 2001; 38: 1734-40.

10. Bramley PM. Is lycopene beneficial to human health. Phytochemistry 2000; 54: 233-36.

11. Rao AV, Agarwal S. Role of antioxidant lycopene in cancer and heart disease. J Am Coll Nutr. 2000; 19: 563 69.

12. DiMascio P, Kaiser S, Sies H. Lycopene as the most efficient biological carotenoid singlet oxygen quencher. Arch Biochem Biophys. 1989; 274: 532-38. 
13. Bansal P, Gupta K, Ojha SK, Nandave M, Mittal R, Kumari S, Arya DS. Cardioprotective effect of lycopene in the experimental model of myocardial ischemia-reperfusion injury. Mol cell Biochem. 2006; 289: 1-9.

14. Khan I. Effect of antioxidant vitamins $\mathrm{E}$ and $\mathrm{C}$ on adrenaline induced myocardial damage in rats. M.Phil. Thesis. University of Dhaka. 1996.

15. Mathieu M. IFCC method for L-aspertate aminotransferase. J Clin Chem Clin Biochem. 1986; 24: 497-10.

16. Lowry $\mathrm{OH}$, Rosebrough $\mathrm{NJ}$, Farr L, Randall RJ. Protein measurement with the folin phenol reagent. J Biol Chem. 1951; 193: 265-75.
17. Hagen TM, Ingersoll RT, Lykkesfeld J, Liu J, Wehr CM, Vinarsky V, Bartholomew JC, Ames BN. (R)-alpha-lipoic acid supplemented old rats have improved mitochondrial function, decreased oxidative damage and increased metabolic rate. FASEB J. 1999; 13: 411-18.

18. Rona G, Chappel Cl, Balazs T, Gaudry R. An infarct like myocardial lesion and other toxic manifestations produced by isoproterenol in the rat. AMA Arch Pathol. 1959; 67: 443-55.

19. Zhang Y, Li Y, Liu B, Wei R, Wang D, Tan X, Bu D, Pang Y, Tang C. Urotensin II accelerates cardiac fibrosis and hypertrophy of rats induced by isoproterenol. Acta Pharmacologica Sinica. 2006; 28: 36-43. 